CORRESPONDFNCF.

\title{
REMAINS OF BOS PRIMIGENIUS RECENTLY FOUND AT SOUTHAMPTON.
}

SIR,-During the progress of the excavation for the purpose of forming a new deep water dock of eighteen acres at Southampton, a fine specimen of the horn cores and part of the skull of Bos primigenius has been found.

The river mud with which the excavation begins is of a thickness varying from ten to fifteen feet, below which a bed of peat resting on dark angular flint gravel occurs. Both the peat and the gravel vary in thickness, as the gravel is found more or less in ridges, in the hollows of which the peat attains its greatest depth. It was from one of these thick masses of peat that the remains of Bos primigenius were net with at a depth of nearly twenty feet below the surface of the mud, which formed the bed of the tidal estuary at this spot.

The skull was found in one piece, and includes the frontal, occipital, temporal, sphenoid (with both wings), and tympanic bones, with fragments of the pterygoids, and of the ethmoids.

The temporal fossa are preserved, and the roof of one orbit, and part of the other; the zygomatic arches are incomplete.

The breadth of the forehead, across the centre, is ten inches, and between the orbits about twelve inches. The length of the forehead as preserved is eleven inches, and the length from the frontal crest to the base of the occipital bone is ten inches. The circumference of the cores of the horns at their roots is sixteen and a quarter inches, and the length of the cores round the curvature about twenty-nine inches. The width apart of the horn cores from tip to tip is thirty-four and a half inches.

The specimen has been placed in the Museum of the Hartley Institution, Southampton.

T. W. SHORE.

\section{PAL EONTOLOGICAL NOMENCLATURE AND THE TRINOMIAL} SYSTEM.

Sir,-An answer given not very long ago in an Examination paper was as follows, "Physical Geography is the work of God, Geology is the work of man." No doubt the candidate who wrote this answer failed to receive full marks; but since the matter was brought to my notice, it has frequently occurred to me that the reply was not altogether inappropriate. Geology and Palæontology are suffering from such an infusion of new and hard names that the ordinary reader and even the hard-working student are often bowildered and baffled in their efforts to comprehend the progress of knowledge. It is not my intention now to discuss any of the new terms applied to our formations and their subdivisions; suffice it to say that most of the suggestions to replace old and well-understood names would, if adopted, be more likely to place obstacles in the path of the inquirer than to assist or encourage his studies. What even more painfully stirs me at the present time is the multiplication 
of generic or subgeneric names of Ammonites, and the confusion that appears to have arisen concerning what have hitherto been regarded as recognizable species.

It is indeed difficult for the "general geologist" to understand and remember the subgeneric names of Ammonites, especially when the form known as Harpoceras concavum has been recently changed again to Lioceras concavum, and $H$. Murchisone has become Ludwigia Murchisona. One cannot help wondering what other changes may be in store for us. It is, however, still more perplexing to be told by one who has devoted especial attention to the subject, and who is in every way qualified to speak with authority, that the form which is "called by D'Orbigny, Wright, and others Am. serpentinus, and is so labelled in museums and private collections, is the Anmonites falcifer of Sowerby." (See S. S. Buckman, Geot. MaG. Sept. 1887, p. 396.) What is then to become of our "Serpentinus-beds"? Again, the same palæontologist tells us that the occurrence of Ammonites Jurensis in England is doubtful, in fact he has never yet ascertained its presence in our strata. (Proc. Cotteswold Club, vol. ix. part 2, 1887.) What then is to become of our "Jurensisbeds"? Once more, the recognition of the true Ammonites Sowerbyi appears to be a source of great difficulty to judge by the remarks made in a recent volume of the Palæontographical Society. (Hudleston, Introduction to Gasteropoda of the Inferior Oolite.) Even the "Sowerbyi-beds" are in trouble!

The question that perhaps naturally arises to an outsider is this, cannot these well-known specific names be applied in a sufficiently comprehensive way to include the forms which the older authorities recognized under the names of $A$. serpentinus, $A$. Jurensis, and $A$. Sowerbyi, respectively?

To go further, would not the adoption of the trinomial system meet all requirements, and be the means not only of doing justice to the more minute and exceedingly important observations made nowa-days, but also of placing the results of this detailed work in a manner more intelligible to the "general geologist"? It would seem likely under present circumstances that some collective grouping of the many species now made must eventually take place, if any individuals except the specialists in each department are to follow the progress of palæontology, or attempt the naming of their fossils: and this grouping might be done under the trinomial system, better, it appears to me, than under the system which introduces subgeneric names. So far as the geologist is concerned, he simply requires a definition of specific characters, and a key to the distribution of each species in time and space. Where particular varieties are confined to special horizons, he can obtain this precise information on the trinomial system. Moreover, the adoption of that system would fulfil all the requirements of the biologist. No doubt many more specimens are available now for study than was formerly the case, and it becomes more and more difficult to draw rigid lines; but there seems to be a tendency to confine specific characters within narrower limits than heretofore, and this perbaps is the real source 
of the difficulty. I should feel much grieved if these remarks appeared to convey any slight whatever on the careful work of modern palæontologists; but my impression is that the object of their labours will be to a serious extent frustrated if their results are published in too complex a form for the "general geologist." Having said so much about changes of names, perhaps I may be pardoned if I sign myself,

Banbury, 8th Sept. 1887.

Ros. W. HadDow.

\section{CHERT IN IRISH CARBONIFEROUS ROCKS,}

Srr,-Chert is not, as supposed by Dr. Hinde, a definite characteristic of the Irish Upper Carboniferous Limestone (see chapter v. Manual of the Geology of Ireland, C. Kegan Paul \& Co., 1878). Where this limestone is fully represented as in Co. Limerick, ete., the "lower cherty zone" is there best developed; and it occurs in the lower limestone, between the "lower shaly limestone" and the "Fenestella Limestone." A second conspicuous zone for chert lies between the Fenestella Limestone and the upper limestone, when of the "Calp type." In the upper limestone of Cork and Kerry there are layers and nodules of chert, but in Limerick, Tipperary, and part of Galway it is rare, while in the rest of Galway and in Clare it is more common. In part of Leinster, between the upper limestone and the Coal-measures lower shales, there is a cherty zone, but in the rest of Leinster and in Munster in all the known sections of the junction of the Limestone and Coal-measure shales, this cherty zone is absent. In Ulster, however, especially Fermanagh, where sections can be seen, this cherty zone is well developed and of a character similar to that described by Dr. Hinde as characteristic of the Yoredale Series, Yorkshire.

According to my experience chert is as frequent, if not more so, in the Lower, as in the Upper Irish Carboniferous Limestone. When it occurs in zones, it is usually accompanied by shaly beds, and is more or less friable; but when in compact limestones like those of the "Burren type," it stands ont conspicunusly like the nodules, lentils, and layers of flint in the chalk, as can be seen in innumerable places in Cork, Kerry, Clare, Sligo, Fermanagh, etc.; near Athenry, Co. Galway, in a railway-cutting, there is a thick bed.

As Dr. Hinde has been making researches as to the origin of chert, I would specially direct his attention to the chert lentils perpendicular to the stratification in Benmore, Co. Fermanagh, to which attention was first drawn by Thos. Plunkett, M.R.I.A., of Enniskillen, in a paper read before the Royal Dublin Society. Those mentioned in his paper occur in Benmore, but 1 have since observed them in Belmore and other places in that county. They are lenticular masses in height and depth, and have all the appearance of ordinary chert. I take it that they are the filling in of shrinkage fissures along a line of partial rupture. I would also draw his attention to the lower and middle cherty zones in the Co. Limerick, both of which are remarkable Palæozoic breaks, as in the intervening rock, "Fenestella Limestone," the fossils are quite distinct and much more 